\title{
Effect of Differentiated Nitrogen Fertilization on the Enzymatic Activity of the Soil for Sweet Potato (Ipomoea batatas L. [Lam.]) Cultivation
}

\author{
Barbara Sawicka ${ }^{1}\left(0\right.$, Barbara Krochmal-Marczak ${ }^{2, *}$, Piotr Pszczółkowski ${ }^{3}($ ), \\ Elżbieta Jolanta Bielińska ${ }^{4}$, Anna Wójcikowska-Kapusta ${ }^{4}$, Piotr Barbaś ${ }^{5}$ and Dominika Skiba ${ }^{1}$ \\ 1 Department of Plant Production Technology and Commodities Science, University of Life Sciences in Lublin, \\ Akademicka 15, 20-950 Lublin, Poland; barbara.sawicka@up.lublin.pl (B.S.); \\ dominika.skiba@up.lublin.pl (D.S.) \\ 2 Department of Plant Production and Food Safety, Krosno State College, Dmochowskiego 12, \\ 38-400 Krosno, Poland \\ 3 Research Station for Cultivar Testing COBORU, Uhnin, 21-211 Dębowa Kłoda, Poland; \\ p.pszczolkowski.inspektor@coboru.gov.pl \\ 4 Institute of Soil Science and Environmental Management, University of Life Sciences in Lublin, \\ Leszczyńskiego 57, 20-950 Lublin, Poland; elzbieta.bielinska@up.lublin.pl (E.J.B.); \\ anna.kapusta@up.lublin.pl (A.W.-K.) \\ 5 Department Agronomy of Potato, IHAR_PIB, Branch in Jadwisin, Szaniawskiego 15 Str., \\ 05-140 Serock, Poland; p.barbas@ihar.edu.pl \\ * Correspondence: barbara.marczak@kpu.krosno.pl; Tel.: +48-508-086-387
}

Received: 7 November 2020; Accepted: 12 December 2020; Published: 15 December 2020

\begin{abstract}
The experiment was conducted between 2015-2017 in the Research Station for Cultivar Testing in Uhnin $\left(51^{\circ} 34^{\prime} \mathrm{N}, 23^{\circ} 02^{\prime} \mathrm{E}\right)$, in Luvisols developed from sandy loam soils. Soil samples for the tests of enzymatic activity were collected after the crop was harvested. The measurements included: the content of dehydrogenases, phosphatases, urease and protease, as well as total organic carbon, total nitrogen and mineral nitrogen in soil, based on standard methods. The research results point to changes in the enzymatic activity of light soil under the influence of varied nitrogen fertilization. In objects fertilized with this ingredient, the activity of the analysed enzymes was significantly higher than in the control soil, except for combinations fertilised with $150 \mathrm{~kg} \mathrm{ha}^{-1} \mathrm{~N}$ characterised by the highest accumulation of $\mathrm{N}^{-N_{3}}{ }^{-}$in soil. The activity of dehydrogenases, phosphatases and urease changed as the nitrogen dose increased. The polynomial regression analysis enabled a better understanding of those dependences. In the case of dehydrogenases, phosphatases and urease, a third-degree curvilinear relation of enzymatic activity to nitrogen fertilisation was observed (a fourth-degree relation was found, with a coefficient $R^{2}$ in those equations amounting to $=0.958$, $0.977,0.979$, respectively) and in the case of protease activity, a fourth-degree relation, with coefficient $R^{2}=0.989$. However, soil acidity did not have a significant influence on either the enzymatic activity or physico-chemical characteristics of soil under the cultivation of sweet potatoes. The C:N ratio turned out to be significantly negatively related to the content of the enzymes dehydrogenase (Adh), phosphatase (AF), urease (AU) and protease (AP) as well as the content of total nitrogen, especially


activity as an indicator of soil reaction to nitrogen fertilization and will enable maintenance of the optimal biological balance of cultivated soils.
\end{abstract}

Keywords: soil; sweet potato; nitrogen fertilization; enzymatic activity; biological balance of soil; field crops 


\section{Introduction}

In modern agriculture, nutrient use efficiency of crops is below $50 \%$ in all agroecological conditions. A large share of nutrients is lost in the soil-plant system [1,2]. Lower nutrient use efficiency is connected to their loss or unavailability due to environmental conditions [1,2]. Low biogen use efficiency increases not only plant production costs but also contamination of the environment. The key strategies of improving nutrient use efficiency include the use of optimal fertilization doses, an efficient source, time and application method, and the use of nutrients appropriate for the species, cultivars and genotypes [2,3]. In terms of the Ipomoea batatas L. [Lam] species, recently introduced to cultivation in Central-Eastern Europe, it is also important to improve nutrient application and use efficiency $[4,5]$. Nutrient use efficiency (NUE) is influenced by genetic and physiological features and the plant-environment interactions [4]. Sawicka et al. [5] showed that nitrogen fertilization stimulates photosynthesis efficiency in sweet potatoes at the end of the vegetation period. The use of fertilizing agent doses exceeding plants' nutrient requirements can lead to changes in the ion balance of soil water, pushing them into groundwater. Considering changes in the agricultural production systems in terms of integrated plant protection, more emphasis should be placed on fertilizer efficiency, plant nutritional balance, fertilizer use structure and their effect on the environment. An efficient fertilization strategy should lead to the utilization of crop potential but not at the expense of the environment. Minerals introduced into the soil as mineral fertilizers are not used to the fullest during plant vegetation [3,4]. Increased fertilization, in particular nitrogen fertilization, and agrotechnological simplifications can result in imbalanced use of minerals and, in consequence, water contamination. Improved nutritional value of food crops, including sweet potatoes, is possible by means of bio-enhancement, i.e., agronomic practices or modern biotechnology. NUE informs the use of extra $\mathrm{N}$ used in the agricultural production system [5-7].

Reasonable nitrogen fertilization has a positive influence on high crop yield; however, as a result of incorrect agrotechnical procedures and unreasonable nitrogen fertilization doses, the proper functioning of entire agrosystems can be disturbed.Various compounds (e.g., mycotoxins and nitrosamine) can form in soil environments and ammonia can accumulate, which could affect the soil enzymes and the enzymatic activity of soil, which is a sensitive index of soil environment changes [8-11]. Research by Bielińska et al. [12], shows that biochemical processes in soil play an important functional and structural role in the dynamics of the plant life cycle. The changes leading to various transformations of organic and mineral nitrogenous compounds in soil include mainly processes related directly to the functioning of living organisms, or the biochemical reactions controlled by enzymes developed by living cells or entering soil after they decompose. At the same time, changes in the activity of soil enzymes reflect the environmental disturbances affecting soil and plants [12,13]. Enzymatic activity in soils depends on a number of factors, such as the content of organic matter, soil $\mathrm{pH}$, the content of biogenic elements, and the quantity and diversity of microorganisms [14,15]. Bielińska et al. [16] and Błońska et al. [17] believe that the enzymatic activity of soil largely depends on nitrogen organic and mineral fertilization. In order to reduce the excessive use of nitrogen fertilizers, the Nitrates Directive was introduced. The basic aim of the Nitrates Directive is to protect waters against pollution caused by nitrates from agricultural sources. To this end, the so-calledAction Programme was introduced on 27 July 2018 [8,9]. The nitrogen dose should be determined in the fertilization plan, nitrogen fertilization plan, or based on the maximum available nitrogen dose from all sources, determined in the Action Programme [10].

Nitrogen fertilization of sweet potatoes has been a subject of a number of experimental studies in order to determine the optimal dose providing high yield. In Poland and in the world, there are no studies on the effect of nitrogen fertilization on the enzymatic activity of soil under the cultivation of sweet potatoes. Since sweet potato is mainly cultivated in light and medium soils, which are particularly prone to leaching, the issue of mineral fertilization, especially with nitrogen, and the determination of the maximum nitrogen dose is very important $[7-10,18,19]$. Therefore, the aim of this study was to determine the influence of differentiated nitrogen fertilization on the enzymatic activity of soil in sweet potato cultivation. Another goal was to determine the effect of nitrogen fertilization on 
the balance of nitrogen forms in the soil. Moreover, the aim of the study was to determine the effect of nitrogen fertilization on the C:N ratio in the soil under sweet potato cultivation. The study adopted 3 alternative hypotheses:

1. the first alternative hypothesis assumes that increasing nitrogen fertilization against the background of constant phosphorus-potassium fertilization will optimize the biological balance in the soil by changing the activity of selected soil enzymes (dehydrogenase, phosphatase, urease and protease), against the null hypothesis that nitrogen fertilization does not cause significant changes in their activity;

2. the second alternative hypothesis assumes that increasing nitrogen fertilization against the background of constant phosphorus-potassium fertilization will change the nitrogen forms in the soil, against the null hypothesis that nitrogen fertilization will not change the balance of nitrogen forms in the soil;

3. the third alternative hypothesis assumes that increasing nitrogen fertilization against the background of constant phosphorus-potassium fertilization will improve the $\mathrm{C}: \mathrm{N}$ ratio, against the null hypothesis that fertilization with this component will not change the C:N ratio.

The results of this research may be the basis for developing a reasonable nitrogen fertilization plan for sweet potato cultivation and at the same time keeping soil in optimal biological balance.

\section{Materials and Methods}

\subsection{Field Research}

The experiment was conducted between 2015-2017 in the Experimental Station for Variety Assessment in Uhnin ( $51^{\circ} 34^{\prime} \mathrm{N}, 23^{\circ} 02^{\prime} \mathrm{E}, \mathrm{H}=157$ metres above sea level), in Luvisols developed from sandy loam soils [20], in the cultivation of sweet potato (Ipomoea batatas L. [Lam.]). The experiment was based on a randomized block design in the three replicates. Differentiated nitrogen fertilization was used $\left(0,50,100,150\right.$ and $\left.200 \mathrm{~kg} \mathrm{ha}^{-1} \mathrm{~N}\right)$, against the background of constant fertilization with phosphorus and potassium ( $39 \mathrm{~kg} \mathrm{ha}^{-1} \mathrm{P}$ and $112 \mathrm{~kg} \mathrm{ha}^{-1} \mathrm{~K}$ ) and a full dose of manure $\left(25 \mathrm{t} \mathrm{ha}^{-1}\right)$ (Table 1). The manure was alkaline. Organic carbon content ranged from $26.87 \%$ to $27.18 \%$. The content of macronutrients was varied, nitrogen ranges from 2.55 to $3.03 \mathrm{~g} \mathrm{~kg}^{-1}$, phosphorus $8.16-9.0 \mathrm{~g} \mathrm{~kg}^{-1}$, potassium $12.9-14.1 \mathrm{~g} \mathrm{~kg}^{-1}$, magnesium $3.12-3.8 \mathrm{~g} \mathrm{~kg}^{-1}$, and calcium 0.25 to $0.54 \mathrm{~g} \mathrm{~kg}^{-1}$.

Table 1. Chemical analysis of manure (2015-2017).

\begin{tabular}{ccccc}
\hline Properties & Unit & $\mathbf{2 0 1 5}$ & $\mathbf{2 0 1 6}$ & $\mathbf{2 0 1 7}$ \\
\hline $\mathrm{pH}$ & $\mathrm{H}_{2} \mathrm{O}$ & 8.90 & 8.70 & 8.67 \\
$\mathrm{pH}$ & $\mathrm{KCl}$ & 8.30 & 8.10 & 8.25 \\
Corg. & $\%$ & 27.18 & 26.87 & 27.09 \\
$\mathrm{~N}$ total & $\%$ & 2.60 & 2.55 & 3.03 \\
$\mathrm{C}: \mathrm{N}$ & & 10.45 & 10.54 & 10.58 \\
Available phosphorus & $\mathrm{mg} \mathrm{kg}^{-1}$ & 834.0 & 803.1 & 812.5 \\
Available potasium & $\mathrm{mg} \mathrm{kg}^{-1}$ & 1232.0 & 1104.6 & 1167.1 \\
Available magnesium & $\mathrm{mg} \mathrm{kg}^{-1}$ & 226.0 & 201.7 & 213.7 \\
P total & $\mathrm{g} \mathrm{kg}^{-1}$ & 9.00 & 8.16 & 8.39 \\
K total & $\mathrm{g} \mathrm{kg}^{-1}$ & 14.10 & 12.9 & 13.12 \\
Mg total & $\mathrm{g} \mathrm{kg}^{-1}$ & 3.80 & 3.12 & 3.54 \\
Ca total & $\mathrm{g} \mathrm{kg}^{-1}$ & 0.25 & 0.44 & 0.54 \\
\hline
\end{tabular}

Source: Felin Experimental Farm.

Nitrogen was used in the form of 32\% ammonium nitrate, 19\% phosphorus (in the form of single superphosphate), and $60 \%$ potassium (in the form of potassium salt). The pre-crop of sweet potato was spring barley. In autumn, organic fertilization was applied in the form of manure as well as phosphorus and potassium fertilization, followed by winter ploughing. In spring, the field was 
harrowed, nitrogen fertilizers were sown up to a dose of $100 \mathrm{~kg} \mathrm{ha}^{-1}$ and mixed with the soil with a cultivation aggregate (cultivator and cage roller). Fertiliser doses over $100 \mathrm{~kg} \mathrm{ha}^{-1}$ were divided and the first dose of $100 \mathrm{~kg} \mathrm{ha}^{-1}$ was used prior to planting, and the remaining part of nitrogen was applied during potato vegetation, on $\mathrm{BBCH}$ stage 69 [21]. The propagating material came from West Guinea and included cuttings of the Canuana cultivar characterized by white skin and yellow flesh [22]. They were obtained from in vitro propagation. The plants were planted on 20 May with $1 \times 1 \mathrm{~m}$ spacing after spring frost. The size of the plots to be harvested was $40 \mathrm{~m}^{2}$. The cultivation was carried out mechanically with no herbicides. Moreover, no plant protection from diseases and pests was applied, because it was not necessary (no diseases and pests). Tubers were harvested in the technical ripeness stage, in early October.

\subsection{Soil Sampling}

Before setting up the experiment, representative soil samples were taken annually; 20 samples from each the field experiment, in order to determine the content of humus, soil $\mathrm{pH}$ and the content of basic macro- and micronutrients in the soil. Soil samples were collected with Egner's stick: Egner's stick was inserted into soil up to the protruding element, then rotated and removed, and the soil from the stick groove was placed in a container labelled 'topsoil'. Then, a 40-cm deep hole was dug up with a spade, the fallen topsoil was removed from the hole, and another sample was collected with the stick and placed in a bucket labelled 'subsoil'.

\subsection{Methodology for the Assessment of Soil Samples}

In soil samples, the following parameters were determined: soil granulometric composition, by laser method [23]; $\mathrm{pH}$, in $1 \mathrm{~mol} \mathrm{KCl} \mathrm{dm}{ }^{-3}$ [24]; organic carbon content (C org), by Tiurin method [25]; and on its basis, the content of humus in the soil was determined [23].

The content of available $\mathrm{P}_{2} \mathrm{O}_{5}$ and $\mathrm{K}_{2} \mathrm{O}$ were determined by the Egner-Riehm method [24,25], and magnesium contentby the Schachtschabel method [26] in the soil was also determined. The content of $\mathrm{Cu}, \mathrm{Mn}, \mathrm{Zn}, \mathrm{Fe}, \mathrm{B}$ was determined in $1 \mathrm{~mol}$ of $\mathrm{HCl}$ [23], and the abundance was determined according to the limit numbers established for this extractant $[27,28]$.

The chemical and physicochemical properties of the soil were determined in a certified laboratory of the District Chemical and Agricultural Station in Krosno according to the methods in force at chemical and agricultural stations in Poland.

\subsection{Testing the Enzymatic Activity and Physico-chemical Characteristics of Soil}

Samples for soil enzymatic activity testing were collected from 20 random locations, from the topsoil $(0-25 \mathrm{~cm})$ from each fertilization variant, and after the crop was harvested [24]. Tests covered the activity of dehydrogenases [15], phosphatases [29], urease [30] and protease [31]. The enzyme activity was determined by the following methods:

- the activity of dehydrogenases was expressed in $\mathrm{cm}^{3} \mathrm{H}_{2}$, required to reduce triphenyltetrazole chloride (TTC) to TFP (triphenyl formazan) [28];

- phosphatases, in moles of p-nitrophenol (PNP), obtained from 4-nitrophenyl phosphate sodium [29];

- urease, in $\mathrm{mg} \mathrm{N}-\mathrm{NH}_{4}{ }^{+}$obtained from hydrolysed urea [31];

- $\quad$ proteases, in mg of tyrosine developed from sodium caseinate [32,33].

- The activity of the tested enzymes was analyzed in soil with natural humidity, and the results were converted into absolutely dry soil mass.

- Simultaneously, the samples were tested for the content of total organic carbon, $\mathrm{pH}_{\mathrm{KCl}}$ and mineral forms of nitrogen $\left(\mathrm{NH}_{4}{ }^{+}-\mathrm{N}\right.$ and $\left.\mathrm{NO}_{3}{ }^{-} \mathrm{N}\right)$ [23].

- dehydrogenases (ADh), by the Thalmann method [28], using a $1 \%$ solution of TTC as a substrate and 96-h incubation at $37^{\circ} \mathrm{C}$, expressing their activity in $\mathrm{cm}^{3} \mathrm{H}_{2} \mathrm{~kg}^{-1} \mathrm{~d}^{-1}$ (for $1 \mathrm{~kg}$ of soil in $24 \mathrm{~h}$ ). 
- phosphatase (AF), by the method of Tabatabai and Bremner [29], using 0.8\% sodium p-nitrophenyl phosphate as a substrate and a 1 hour incubation at $37^{\circ} \mathrm{C}$; enzyme activity was expressed in mmol PNP kg-1 $\mathrm{h}^{-1}$ (p-nitrophenol per $1 \mathrm{~kg}$ of soil in $1 \mathrm{~h}$ );

- urease (AU), by the method of Zantu and Bremner [30], using a 2.5\% urea solution as a substrate and an 18 -h incubation at $37^{\circ} \mathrm{C}$, expressing the enzyme activity in mg $\mathrm{N}-\mathrm{NH}_{4}+\mathrm{kg}^{-1} \mathrm{~h}^{-1}$ $\mathrm{N}-\mathrm{NH}_{4}+($ for $1 \mathrm{~kg}$ of soil in $1 \mathrm{~h}$ );

- $\quad$ proteases (AP), by the method of Ladd and Butler [31], using a 1\% solution of sodium caseinate as a substrate and using a 1-h incubation at $50{ }^{\circ} \mathrm{C}$, expressing the enzyme activity in mg of tyrosine $\mathrm{kg}^{-1} \mathrm{~h}^{-1}$ (per $1 \mathrm{~kg}$ of soil in $1 \mathrm{~h}$ ).

\subsection{Statistical Analysis}

Statistical analyses were based on a two-factor analysis of variance and T-Tukey's multiple tests, with the assumed significance level $\alpha=0.05$. The models of analysis of variance with the main effects of the factors studied and their interactions were used. The detailed analysis only dealt with the main effects. The calculations were made with the SAS Enterprise 4.2 software [34]. T-Tukey's multiple comparison tests enabled detailed comparative analyses of averages, by isolating statistically homogeneous medium groups (homogeneous groups) and determining the so-called least significant mean differences (LSD), which in Tukey's tests are marked by HSD (Tukey's Honest Significant Difference) [35]. The calculated p-values determine the significance and magnitude of the impact of the studied factors on the differentiation of the results of the analyzed variables, by comparing them with the most frequently accepted levels of alpha significance $(0.05,0.01)$. In case of detailed analyses based on T-Tukey's multiple tests, the assumed significance level was $\alpha=0.05$. Letter indicators at averages determine the so-called homogeneous groups (statistically homogeneous). The occurrence of the same letter pointer at averages (at least one) means that there is no statistically significant difference between them. The sizes of HSD play an auxiliary role, allowing quantification of the differences between means in a quantitative way.

\subsection{Weather Conditions}

The pattern of air temperature and precipitation varied in the study years (Figure 1).

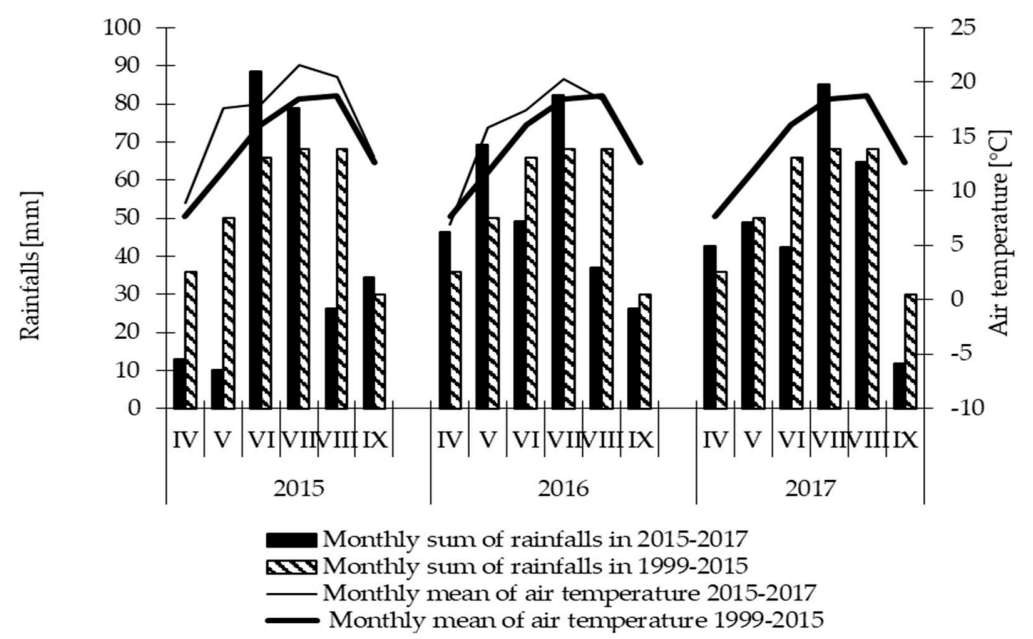

Figure 1. The distribution of rainfall and air temperatures during the growing season of Ipomoea batatas according to the meteorological station at the Research Station for Cultivar Testing in Uhnin (2015-2017).

The year 2015 was characterised by draught in April-May and August-September, whereas the years 2016-2017 can be described as humid. In that period, the first half of vegetation was wet and warm, whereas the second was dry. 


\section{Results}

\subsection{Soil Characteristics Prior to the Experiment}

The results of soil granulometric analysis and some physico-chemical properties of soil are presented in Table 2.

Table 2. The granulometric composition of soil before establishing the experiment in 2015-2017.

\begin{tabular}{|c|c|c|c|c|}
\hline \multirow{3}{*}{ Year } & \multicolumn{3}{|c|}{ Composition of the Granulometric Fractions (\%) } & \multirow{3}{*}{ Soil Classification } \\
\hline & $\begin{array}{c}\text { Sand } \\
2.0-0.05\end{array}$ & $\begin{array}{c}\text { Silt } \\
0.05-0.002\end{array}$ & $\begin{array}{c}\text { Clay } \\
<0.002\end{array}$ & \\
\hline & \multicolumn{3}{|c|}{ mm } & \\
\hline 2015 & 67.14 & 30.29 & 2.56 & medium soil \\
\hline 2016 & 67.04 & 30.24 & 2.72 & medium soil \\
\hline 2017 & 67.47 & 30.45 & 2.08 & medium soil \\
\hline Average & 67.22 & 30.33 & 2.45 & medium soil \\
\hline
\end{tabular}

Source: Results of own experiment conducted in the Chemical and Agricultural Station in Lublin.

The experiment was carried out on sandy loam soil type. According to the content of sand, silt and clay fraction, this is the granulometric subgroup of clay sand (medium soil). Soil granulometric composition was determined by means of the aerometric method by Prószyński [36]. The fraction of sand was $67.22 \%$, the silt fraction was $30.33 \%$ and the clay was $2.45 \%$ (Table 1 ). This proportion of individual fractions corresponds to the composition of clayey dust. In terms of agricultural suitability, these soils belong to slightly acidic good rye complex. This soil is classified in the agronomic category of medium mineral [23]. The soil content of assimilable components was as follows: phosphorus-high and very high (21.0 mg $100 \mathrm{~g}^{-1} \mathrm{P}_{2} \mathrm{O}_{5}$ of soil), magnesium — high (7.1 mg $100 \mathrm{~g}^{-1} \mathrm{Mg}$ of soil), potassium-low and medium (11.9 mg $100 \mathrm{~g}^{-1} \mathrm{~K}_{2} \mathrm{O}$ of soil), copper and zinc-high (7.12 $\mathrm{mg} \mathrm{kg}^{-1} \mathrm{Cu}$ of soil, $45.96 \mathrm{mg} \mathrm{kg}^{-1}$ $\mathrm{Zn}$ of soil), and manganese and iron-medium ( $275 \mathrm{mg} \mathrm{kg}^{-1} \mathrm{Mn}$ of soil, $3755 \mathrm{mg} \mathrm{kg}^{-1} \mathrm{Fe}$ of soil). In the case of boron, the average was high, about $6.25 \mathrm{mg} \mathrm{kg}^{-1} \mathrm{~B}$ of soil (Table 3).

Table 3. Physico-chemical characteristics of the soil before establishing the experiment in 2015-2017.

\begin{tabular}{|c|c|c|c|c|c|c|c|c|c|c|}
\hline \multirow[t]{2}{*}{ Year } & \multicolumn{3}{|c|}{$\begin{array}{l}\text { Content of Available } \\
\text { Macronutrients } \\
\text { (mg } 100 \mathrm{~g}^{-1} \text { soil) }\end{array}$} & \multirow{2}{*}{$\begin{array}{l}\text { Humus } \\
\text { Content } \\
(\%)\end{array}$} & \multirow[t]{2}{*}{$\underset{(\mathrm{KCl})}{\mathrm{pH}}$} & \multicolumn{5}{|c|}{$\begin{array}{l}\text { Micronutrients Content } \\
\quad\left(\mathrm{mg} \mathrm{kg}^{-1} \text { soil }\right)\end{array}$} \\
\hline & $\mathbf{P}_{2} \mathrm{O}_{5}$ & $\mathrm{~K}_{2} \mathrm{O}$ & Mg & & & $\mathrm{Cu}$ & Mn & $\mathrm{Zn}$ & $\mathrm{Fe}$ & B \\
\hline 2015 & 20.2 & 13.0 & 7.7 & 0.93 & 5.90 & 7.60 & 320 & 39.98 & 3770 & 7.31 \\
\hline 2016 & 18.8 & 11.1 & 7.1 & 1.08 & 5.79 & 4.85 & 335 & 56.87 & 3899 & 5.37 \\
\hline 2017 & 24.1 & 11.6 & 6.4 & 1.05 & 6.65 & 8.90 & 171 & 41.04 & 3596 & 6.06 \\
\hline Average & 21.0 & 11.9 & 7.1 & 1.02 & 6.11 & 7.12 & 275 & 45.96 & 3755 & 6.25 \\
\hline
\end{tabular}

Source: Results of own experiment conducted in the Central Research Laboratory of the University of Life Science in Lublin.

The average acidity of the soil (pH), in a $\mathrm{KCl}$ solution, in 2015 was 5.90, 5.79 in 2016, and 6.65 in 2017; these values allowed the classification of the experimental soil as slightly acidic soil. The humus content in the arable layer was low and the amount of humus formed ranged from $0.93 \%$ to $1.08 \%$.

\subsection{Variability of Soil Enzymatic Activity}

The research results point to evident changes in the enzymatic activity of light soil under the influence of differentiated nitrogen fertilization. In soils of most objects fertilized with this ingredient, the activity of the analysed enzymes was significantly higher than in the control soil (without nitrogen fertilization), except for combinations fertilized with $150 \mathrm{~kg} \mathrm{ha}^{-1} \mathrm{~N}$ characterised by the highest 
accumulation of ${\mathrm{N}-\mathrm{NO}_{3}}^{-}$in soil (Tables 4 and 5). Enzyme activity during vegetation periods depended mainly on individual characteristics of the enzyme under study. A significant influence of study years on soil enzymatic activity was observed only in the case of phosphatases and protease. The highest average activity of phosphatases was recorded in 2015, and of proteasein 2016, which was related to the different reaction of enzymes to atmospheric conditions in the study years (Table 4).

Table 4. Enzymatic activity of soil under cultivation of sweet potato (Ipomoea batatas L. [Lam.]).

\begin{tabular}{|c|c|c|c|c|c|}
\hline \multirow{2}{*}{\multicolumn{2}{|c|}{ Experimental Factors }} & \multicolumn{4}{|c|}{ Biological Activity of Soil } \\
\hline & & $\begin{array}{c}\text { Dehydrogenase } \\
\left(\mathrm{cm}^{3} \mathrm{H}_{2} \mathrm{~kg}^{-1} \mathrm{~d}^{-1}\right)\end{array}$ & $\begin{array}{c}\text { Phosphatase } \\
\text { (mmol PNP } \\
\left.\mathrm{kg}^{-1} \mathrm{~h}^{-1}\right)\end{array}$ & $\begin{array}{c}\text { Urease } \\
\left(\mathrm{mg} \mathrm{NH}_{4} \mathrm{NO}_{3}+\mathrm{kg}^{-1} \mathrm{~h}^{-1}\right)\end{array}$ & $\begin{array}{c}\text { Protease } \\
\text { (mg tyrosine } \\
\left.\mathrm{kg}^{-1} \mathrm{~h}^{-1}\right)\end{array}$ \\
\hline \multirow{6}{*}{$\begin{array}{l}\text { Nitrogen } \\
\text { fertilization } \\
\left(\mathrm{kg} \mathrm{ha}^{-1}\right)\end{array}$} & 0 & 1.92 & 7.82 & 12.23 & 16.15 \\
\hline & 50 & 2.81 & 9.25 & 15.10 & 17.22 \\
\hline & 100 & 2.14 & 8.87 & 14.56 & 17.77 \\
\hline & 150 & 2.04 & 7.94 & 12.86 & 16.47 \\
\hline & 200 & 2.99 & 10.04 & 15.94 & 17.49 \\
\hline & $\mathrm{HSD}_{0.05}$ & 0.20 & 0.73 & 1.82 & 1.42 \\
\hline \multirow{4}{*}{ Years } & 2015 & 2.41 & 8.92 & 14.17 & 16.63 \\
\hline & 2016 & 2.37 & 8.56 & 14.15 & 17.52 \\
\hline & 2017 & 2.36 & 8.87 & 14.09 & 16.91 \\
\hline & $\mathrm{HSD}_{0.05}$ & $\mathrm{~ns}^{*}$ & 0.35 & $\mathrm{~ns}^{*}$ & 0.85 \\
\hline \multicolumn{2}{|c|}{ Average } & 2.38 & 8.78 & 14.14 & 17.02 \\
\hline
\end{tabular}

Table 5. Selected chemical properties of soil under cultivation of sweet potato (Ipomoea batatas L. [Lam.]).

\begin{tabular}{|c|c|c|c|c|c|c|c|}
\hline \multicolumn{2}{|c|}{ Experimental Factors } & $\begin{array}{c}\mathrm{C} \\
\left(\mathrm{g} \mathrm{kg}^{-1}\right)\end{array}$ & $\begin{array}{c}\text { Total } \\
\text { Nitrogen } \\
\left(\mathrm{g} \mathrm{kg}^{-1}\right)\end{array}$ & $\begin{array}{c}\text { C:N } \\
\text { Ratio }\end{array}$ & $\begin{array}{l}\mathrm{N}-\mathrm{NO}_{3}^{-} \\
\left(\mathrm{mg} \mathrm{kg}^{-1}\right)\end{array}$ & $\begin{array}{c}\mathrm{N}-\mathrm{NH}_{4}{ }^{+} \\
\left(\mathrm{mg} \mathrm{kg}^{-1}\right)\end{array}$ & $\mathrm{pH}_{\mathrm{KCl}}$ \\
\hline \multirow{6}{*}{$\begin{array}{l}\text { Nitrogen fertilization } \\
\qquad\left(\mathrm{kg} \mathrm{ha}^{-1}\right)\end{array}$} & 0 & 11.50 & 0.95 & 12.11 & 12.76 & 19.28 & 6.80 \\
\hline & 50 & 11.22 & 0.98 & 11.45 & 6.27 & 32.38 & 7.08 \\
\hline & 100 & 13.56 & 1.18 & 11.46 & 5.83 & 30.21 & 6.98 \\
\hline & 150 & 11.38 & 1.04 & 10.95 & 15.15 & 35.52 & 6.70 \\
\hline & 200 & 12.92 & 1.22 & 10.59 & 14.18 & 36.43 & 6.33 \\
\hline & $\mathrm{HSD}_{0.05}$ & 0.61 & 0.05 & 0.56 & 0.54 & 1.53 & 0.34 \\
\hline \multirow{4}{*}{ Years } & 2015 & 12.01 & 1.07 & 11.22 & 10.67 & 30.65 & 7.06 \\
\hline & 2016 & 12.22 & 1.06 & 11.53 & 10.90 & 30.76 & 6.68 \\
\hline & 2017 & 12.13 & 1.08 & 11.23 & 10.94 & 30.88 & 6.60 \\
\hline & $\mathrm{HSD}_{0.05}$ & $\mathrm{~ns}^{*}$ & ns & ns & ns & ns & 0.20 \\
\hline \multicolumn{2}{|l|}{ Average } & 12.12 & 1.07 & 11.31 & 11.31 & 30.76 & \\
\hline
\end{tabular}

The intensity of biochemical processes in soil depended on the type of enzyme, which is connected to the individual enzyme sensitivity to environmental factors and the content of particular substrates for enzyme reactions in soil. And so, the activity of dehydrogenases, phosphatases and urease changed as the nitrogen dose increased; a significant increase in their activity was recorded in objects with $50 \mathrm{~kg} \mathrm{ha}^{-1} \mathrm{~N}$. Another significant increase in the activity of dehydrogenases and phosphatases, as compared to the $50 \mathrm{~kg} \mathrm{ha}^{-1} \mathrm{~N}$ dose, was observed in variants fertilized with $200 \mathrm{~kg} \mathrm{ha}^{-1} \mathrm{~N}$. The influence of nitrogen fertilization on the activity of proteases was least visible. The highest enzymatic activity, as compared to the control object, was recorded in objects with $100 \mathrm{~kg} \mathrm{ha}^{-1} \mathrm{~N}$, whereas an increase in fertilization of $200 \mathrm{~kg} \mathrm{~N} \mathrm{ha}^{-1}$ did not result in significant changes in the enzyme activity (Table 4). 
The polynomial regression analysis enabled a better understanding of those dependences. In the case of dehydrogenases, phosphatases and urease, a third-degree curvilinear relation of enzymatic activity to nitrogen fertilisation was observed (fourth-degree relation was found, with a coefficient $R^{2}$ in those equations amounted to $=0.958,0.977,0.979$, respectively) (Figures 2-4), and in the case of protease activity, a fourth-degree relation, with coefficient $R^{2}=0.989$ (Figure 5). However, it should be noted that the analyses were carried out on a limited number of samples, and that this relationship is not $1.00(100 \%)$, and therefore other factors than the function model (e.g., epiphytes is of fungal diseases) may have contributed to the emergence of such a model.

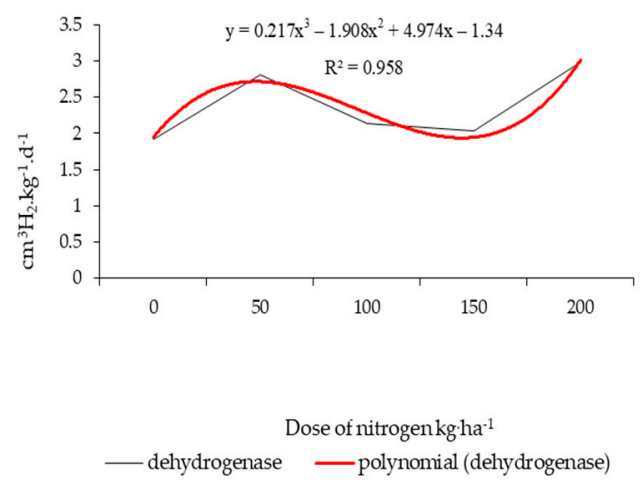

Figure 2. Partial dependence of dehydrogenase for nitrogen fertilization.

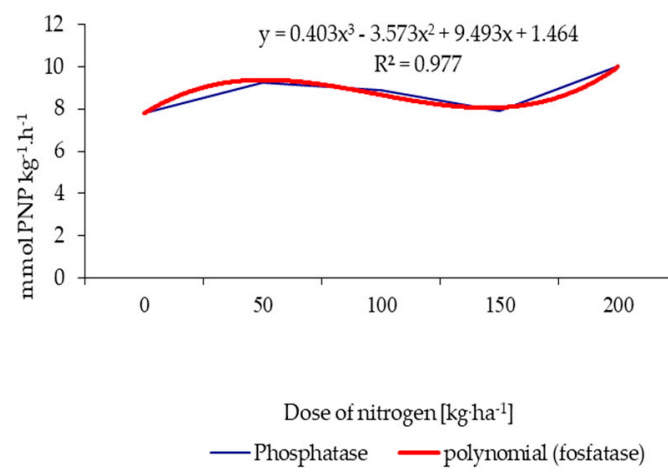

Figure 3. Partial dependence of phosphatase for nitrogen fertilization.

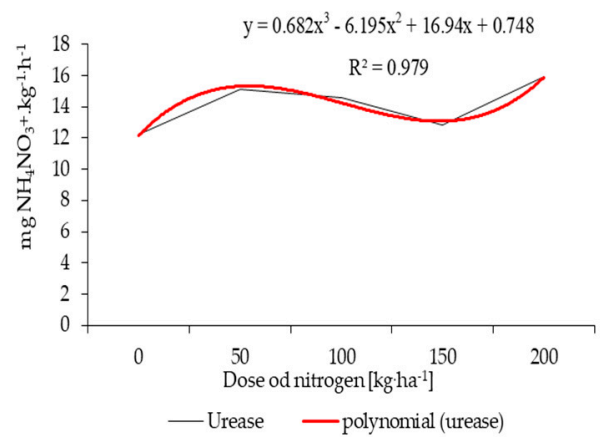

Figure 4. Partial dependence of urease for nitrogen fertilization. 


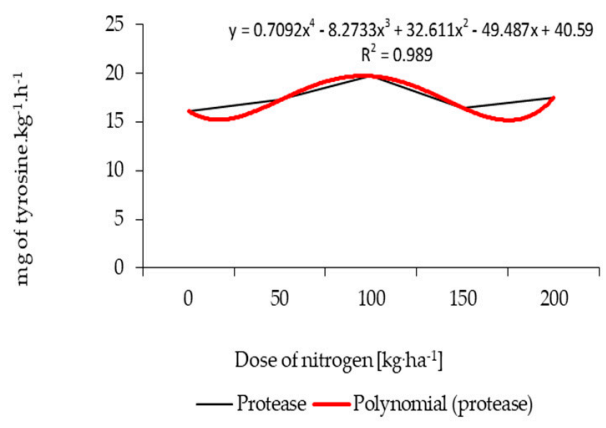

Figure 5. Partial dependence of protease for nitrogen fertilization.

\subsection{Variability of Physico-Chemical Characteristics of Soil}

A significant influence of nitrogen fertilization on the increase of the content of total organic carbon and total nitrogen in soil was recorded in the case of using $100 \mathrm{~kg} \mathrm{ha}^{-1} \mathrm{~N}$. Further increases of nitrogen doses did not result in significant changes of those elements in soil. Increasing doses of nitrogen significantly affected the limitation of the C:N ratio (Table 5), which points to an increase of the rate of organic matter mineralization and humification. The content of ammoniacal nitrogen in soil from nitrogen-fertilised objects was approximately 2.0 times higher than in the control soil. In the case of $\mathrm{NO}_{3}{ }^{-} \mathrm{N}$, a significant increase of this nitrogen form in the analysed soil was recorded only with higher nitrogen doses: 150 and $200 \mathrm{~kg} \mathrm{ha}^{-1} \mathrm{~N}$. It is noteworthy that in soil from objects fertilized with $50 \mathrm{~kg}$ and $100 \mathrm{~kg} \mathrm{ha}^{-1} \mathrm{~N}$, the content of this ingredient was approximately 2 times higher than in the control soil with no nitrogen fertilization (Table 5).

This could be related to increased biological sorption in soil from objects characterised by higher enzymatic activity than the control soil (Table 4). Furthermore, the introduction of high doses of nitrogen fertilizers to soil resulted in microorganisms and plants not being able to utilize the available resources of this element. Increased supply of nitrogen to the soil environment resulted in decreased immobilization of $\mathrm{N}$ into microbiological biomass, and increased net $\mathrm{N}$ mineralization. In the conducted experiment, the average mineral $\mathrm{N}$ content $\left(\mathrm{N}_{-} \mathrm{NH}_{4}{ }^{+}+\mathrm{N}^{-\mathrm{NO}_{3}}{ }^{-}\right)$in the control soil with no nitrogen fertilization amounted to $32.04 \mathrm{mg} \mathrm{kg}^{-1}$, that is $96.12 \mathrm{~kg} \mathrm{~N} \mathrm{ha}^{-1}$, and in soil from objects with higher nitrogen doses (150 and $200 \mathrm{~kg} \mathrm{ha}^{-1} \mathrm{~N}$ )—to approximately $50.6 \mathrm{mg} \mathrm{ha}^{-1}$-approximately $150 \mathrm{~kg} \mathrm{ha}^{-1} \mathrm{~N}$ respectively (Table 5). The analysis of simple correlation between enzymatic activity and physico-chemical characteristics of soil shows that dehydrogenase was highly positively correlated with phosphatase and urease, and slightly less so with protease. However, soil acidity did not have a significant influence on either the enzymatic activity or physico-chemical characteristics of soil under the cultivation of Ipomoea batatas. The enzymatic activity of the enzymes under study turned out to be significantly positively related with the content of total nitrogen, ammoniacal nitrogen and carbon. A strong positive relation was also recorded between the amount of nitrogen and carbon in soil. Moreover, the content of ammoniacal and nitric nitrogen was negatively correlated with the value of the C:N ratio (Table 6).

Descriptive statistics used in this study enabled a better description of the enzymatic activity and physico-chemical characteristics of soil (Table 7). 
Table 6. Pearson's simple correlation coefficients between enzymatic activity and soil physicochemical properties.

\begin{tabular}{|c|c|c|c|c|c|c|c|c|c|c|}
\hline Specification & Adh & AF & AU & AP & $\mathrm{N}-\mathrm{NO}_{3}$ & $\mathbf{N}-\mathbf{N H}_{4}$ & $\mathrm{pH}$ & C & $\mathbf{N}$ & C:N \\
\hline Adh & 1.00 & & & & & & & & & \\
\hline $\mathrm{AF}$ & $0.85^{* *}$ & 1.00 & & & & & & & & \\
\hline $\mathrm{AU}$ & $0.90 * *$ & $0.91 * *$ & 1.00 & & & & & & & \\
\hline $\mathrm{AP}$ & $0.41^{*}$ & $0.49 *$ & $0.59 * *$ & 1.00 & & & & & & \\
\hline $\mathrm{N}-\mathrm{NO}_{3}$ & -0.12 & -0.22 & $-0.35^{*}$ & $-0.39 *$ & 1.00 & & & & & \\
\hline $\mathrm{N}-\mathrm{NH}_{4}$ & $0.59 * *$ & $0.55^{* *}$ & $0.64^{* *}$ & $0.38^{*}$ & 0.10 & 1.00 & & & & \\
\hline $\mathrm{pH}$ & -0.07 & 0.10 & 0.00 & -0.08 & -0.13 & -0.03 & 1.00 & & & \\
\hline $\mathrm{C}$ & $0.39 *$ & $0.46^{* *}$ & $0.50 * *$ & $0.53^{* *}$ & -0.25 & 0.21 & 0.08 & 1.00 & & \\
\hline $\mathrm{N}$ & $0.38^{*}$ & $0.60^{* *}$ & $0.66^{* *}$ & $0.49 *$ & 0.00 & $0.56^{* *}$ & 0.06 & $0.80^{* *}$ & 1.00 & \\
\hline C:N & $-0.56^{* *}$ & $-0.51 * *$ & $-0.56^{* *}$ & $-0.38^{*}$ & $-0.37 *$ & $-0.88^{* *}$ & -0.01 & -0.23 & $-0.64^{* *}$ & 1.00 \\
\hline
\end{tabular}

Adh-dehydrogenase, AF-phosphatases, AU-urease, AP-protease, N-NO ${ }_{3}$-Nitrate- $\mathrm{NO}_{3} ; \quad \mathrm{N}-\mathrm{NH}_{4}-$ Ammonium-Nitrogen; $\mathrm{C}$ - carbon; $\mathrm{N}$-nitrogen; $\mathrm{C}: \mathrm{N}-$ Carbon to Nitrogen ratio. Significant at $p \leq 0.05$; ${ }^{\text {significant }}$ at $p \leq 0.01$ level.

Table 7. Selected statistical features of enzymatic activity and physico-chemical properties of soil under sweet potato cultivation.

\begin{tabular}{ccccccccccc}
\hline Specification & $\mathbf{A d h}$ & $\mathbf{A F}$ & $\mathbf{A U}$ & $\mathbf{A P}$ & $\mathbf{N}-\mathbf{N O}_{3}$ & $\mathbf{N}-\mathbf{N H}_{4}$ & $\mathbf{p H}$ & $\mathbf{C}$ & $\mathbf{N}$ & $\mathbf{C : N}$ \\
\hline Average & 2.38 & 8.78 & 14.14 & 17.02 & 10.84 & 30.76 & 7.77 & 12.12 & 1.07 & 11.28 \\
\hline Median & 2.13 & 8.85 & 14.55 & 16.78 & 12.79 & 32.38 & 7.10 & 11.51 & 1.04 & 11.30 \\
\hline $\begin{array}{c}\text { Statistical } \\
\text { deviations }\end{array}$ & 0.45 & 0.94 & 1.44 & 0.95 & 4.13 & 6.45 & 1.38 & 0.98 & 0.11 & 0.56 \\
\hline Kurtosis & -1.83 & -0.25 & -1.63 & 3.55 & -2.00 & 0.06 & -1.01 & -1.61 & -1.79 & -0.80 \\
\hline Skewness & 0.43 & -0.36 & -0.18 & 1.73 & -0.34 & -1.13 & 0.81 & 0.57 & 0.29 & 0.16 \\
\hline Minimum & 1.88 & 6.87 & 12.15 & 16.02 & 5.72 & 17.93 & 6.20 & 11.14 & 0.94 & 10.40 \\
\hline Maximum & 3.04 & 10.18 & 16.02 & 19.69 & 15.39 & 37.59 & 10.39 & 13.68 & 1.24 & 12.30 \\
\hline $\begin{array}{c}\text { Coefficient } \\
\text { of variation } \\
(\%)\end{array}$ & 18.91 & 10.67 & 10.16 & 5.61 & 38.09 & 20.96 & 17.72 & 8.09 & 10.53 & 4.96 \\
\hline
\end{tabular}

Explanation as in Table 5.

The properties under study were analysed in terms of standard deviation from the arithmetic mean. The negative value of kurtosis as a measure of the concentration of results around the mean, or a flat-topped distribution (platykurtic distribution), points to greater dispersion of results around the mean. Obviously, this is not the only option-it is possible that the distribution of this characteristic in population is platykurtic. Skewness, which is the measure of the asymmetry of results, tells us how the results for that variable are distributed around the mean and if most of the observed results belong to the left side of the mean, close to the mean or to the right side of the mean. The coefficient of skewness above 0 points to a right-side asymmetry of the distribution (positive skew), whereas a result below 0 points to a left-side asymmetry of the distribution (negative skew). The coefficient of variation is a measure independent from the scale of units and is expressed as a percent. A value above $10 \%$ means the variation of this characteristic is significant, whereas a value below $10 \%$ means the variation is statistically insignificant. The most stable soil characteristic turned out to be the C:N ratio, whereas the least stable was $\mathrm{N}-\mathrm{NO}_{3}$ (Table 7).

\section{Discussion}

The conducted research showed that the factor determining the enzymatic activity and chemical properties of soil under the cultivation of sweet potato was the level of nitrogen fertilization. Differentiated nitrogen doses caused significant changes to soil productivity measured by means of its 
enzymatic activity and chemical properties. In a research by Natywa et al. [37], high doses of nitrogen used on corn crops resulted in lower dehydrogenases activity and had no positive effect on the number of actinobacteria or fungi. It is also important to remember that the research was conducted on soil with a higher sorption index and included higher nitrogen fertilization doses $\left(0-240 \mathrm{~kg} \mathrm{ha}^{-1}\right)$. In turn, studies by Sawicka et al. [5] on physiological activity of Ipomoea batatas showed that the minimum chlorophyll fluorescence yield (F0), non-photochemical fluorescence quenching coefficient (qN) and electron transport rate (ETR) were most favourable in the plots fertilized at a rate of $150 \mathrm{~kg} \mathrm{~N} \mathrm{ha}^{-1}$. High activity of dehydrogenases in objects with higher nitrogen fertilization might have resulted from higher concentration of root exudates secreted by the root system of sweet potato. High dehydrogenase activity in the soil under sweet potato cultivation in objects with high nitrogen fertilization resulted from a 3-degree polynomial dependence on nitrogen dose. This relationship is confirmed by the high coefficient of determination of this function $\left(R^{2}=0.958\right)$. According to Bielińska et al. [12] andBielińska and Mocek-Płóciniak [38], root exudates are an excellent source of nutrients for microbes, especially those residing in the rhizosphere. Similar results were also reported by Koper et al. [39], Natywa et al. [37] and Majchrzak et al. [40]. In turn, according to Vetanovetz and Peterson [41], Barabasz et al. [11] and Burns et al. [42], mineral nitrogen fertilisation increases the population of bacteria, actinobacteria and fungi due to the increased amount of nitrogen in soil and changes of its physico-chemical characteristics. Natywa et al. [37] proved that varied nitrogen fertilization and crop growth stages have a significant influence on the quantity of microbes and the activity of enzymes in soil. A larger number of the groups of microbes under study were observed in summer, and a smaller number in spring. In turn, the activity of dehydrogenases in their research was the highest in spring (prior to planting) and in summer, and the lowest in spring right after crop emergence.

High doses of nitrogen did not stimulate the quantity of microbes or enzyme activity (except for year 2 of analyses, when the activity of dehydrogenases was higher in heavily fertilised objects). According to them, too high doses of this ingredient can lead to accumulation of toxic substances, e.g., ammonia poisonous to plants and hampering the growth of some groups of microbes, and can result in lower soil $\mathrm{pH}$, which is crucial for enzyme activity [43,44]. This was also confirmed in our own studies. According to Gostkowska et al. [14], nutrients from mineral fertilisers can be non-absorbable due to lack of the required activity of soil microorganisms. According to Yang et al. [45], various fertilisers can affect the soil enzymatic activity and fertility dynamics. They claim that the enzymatic activity of soil, measured by the activity of phosphatases, catalase, urease and invertase, decreases at the initial stage of crop growth and increases when plants are supplied with substances from partly decomposed manure, because mineral nitrogen reduces soil enzymatic activity, but phosphorus and potassium from fertilizers make up for it. Kucharski et al. [46] found out that in the case of mineral nitrogen fertilization, too high doses of this ingredient $\left(240 \mathrm{~kg} \mathrm{ha}^{-1}\right)$ can lead to a significant decrease in the activity of dehydrogenases, which has not been confirmed in the conducted research. According to Smyk et al. [47], too high doses of nitrogen result in modification of qualitative composition of biocenoses due to the decline of Arthrobacter, Nitrobacter, and Streptomyces bacteria, the dominants of the autochthonous microflora, whereas the largest share of the microbiocenosis is composed of other species, mainly Deuteromycetes fungi.

According to Natywa et al. [37], the factors that influence the emergence of soil microbe groups, except for $\mathrm{pH}$, can also include the content of organic matter and particular elements, soil temperature, cultivation technology, and plant protection methods. Based on two tests of carbon and nitrogen content in the vegetation period, the research by Natywa et al. [48] showed that the time of sample collection and the nitrogen dose do not have a significant influence on the amount of these ingredients in soil. Nevertheless, beneficial chemical properties of soil can stimulate its microbiological and enzymatic activity. In the studies by Sekaran et al. [15] the addition of $\mathrm{N}$ increased the total PLFA in N fertilization treatments in Panicum virgatum L., namely medium (5946 ng PLFA-C in soil) and high doses of nitrogen (5871 ng PLFA-C in soil). The activity of carbon and nitrogen in the biomass of microorganisms and enzymes (urease, $\beta$-glucosidase, acid phosphatase and arylsulfatase) was significantly increased as 
a result of nitrogen fertilization (medium and high doses of $\mathrm{N}$ ), compared to the control (low doses of $\mathrm{N})$, as standard fertilization. Urease activity under the influence of medium $\left(36.3 \mu \mathrm{mol} \mathrm{N}-\mathrm{NH} 4^{+}\right.$ $\mathrm{g}^{-1}$ soil $\left.\mathrm{h}^{-1}\right)$ and high doses of $\mathrm{N}\left(31.4 \mu \mathrm{mol} \mathrm{N}-\mathrm{NH}_{4}^{+} \mathrm{g}^{-1}\right.$ soil $\left.^{-1}\right)$ was respectively by $42.9 \%$ and $23.6 \%$ higher than the low doses of $\mathrm{N}$. This study suggests that applying an average dose of $\mathrm{N}$ on the slope of the feet to the sward may improve the biological properties of the soil and thus protect the environment from excessive nitrogen fertilization. According to Tarafdar and Classen [49], plants are characterised by a varying amount of direct absorption of inorganic phosphorus. Therefore, phosphorus from organic compounds has to hydrolyze with the participation of soil phosphatases whose main sources are soil microorganisms and fungi. Plants take up absorbable phosphorus through the root system. Usually, the activity of soil phosphatases decreases significantly with the increasing content of mineral nitrogen. According to the research by Koper et al. [39], mineral nitrogen fertilization causes insignificant changes in the activity of phosphatases and the content of phosphorus fractions. In our research, we have confirmed a third-degree curvilinear relation between the activity of phosphatases and nitrogen fertilization.

Enzyme activity in soil depends on a number of factors. They include, for example, the content of organic matter, soil $\mathrm{pH}$, the content of biogenic elements, and the quantity and condition of microorganism species [33,38]. Šimek and Hopkins [50] believe that there is a simple relation between soil $\mathrm{pH}$ and DEA or DP and that lower soil $\mathrm{pH}$ leads to reduced denitrification and vice versa. The effect of artificially increasing the $\mathrm{pH}$ to a value close to 6.3 by addition of $\mathrm{NaOH}$ was a substantial increase of DEA, DP and RESP. The optimum $\mathrm{pH}$ value for DP was between 7 and 8 . Nazarkiewicz and Kaniuczak [51] studied the influence of liming and mineral fertilization on the enzymatic activity of Luvisols developed from loess. They found that liming increases the enzymatic activity of dehydrogenases and phosphatases, whereas mineral fertilization decreases the activity of dehydrogenases and proteases. Moreover, they have shown that liming and mineral fertilisation acting together influence the enzymatic activity of dehydrogenases, phosphatases and proteases in limed soil. According to Koper et al. [52], Bielińska and Mocek- Płóciniak [38], Natywa et al. [48] and Wang et al. [13], the cultivation system, as well as various agrotechnical procedures, such as the correct crop rotation, the amount and type of fertilization, and the species and cultivar of crops, also have a great influence of the enzymatic activity and thus the fertility of soil.

During this research, an analysis of the simple correlation between soil $\mathrm{pH}$ and enzyme activity and physico-chemical characteristics of soil was conducted, which showed that this factor has no influence on soil properties. We also proved statistically significant relations between enzymatic activity of soil enzymes and the content of total and ammoniacal nitrogen and carbon. A strong positive relation was also recorded between the amount of nitrogen and carbon in soil. It was also recorded that the content of ammoniacal and nitric nitrogen was negatively related with the value of the C:N ratio. All transformations of biogenic substances in soil are stimulated by enzymes, determining their transfer into forms accessible to plants and microorganisms. Enzymatic tests are among the most sensitive indicators of ecosystem functioning [13]. Mijangos et al. [53] concluded that the activity of dehydrogenases is one of the most sensitive to cultivation treatments. They also observed that biological parameters at first have higher values and are sensitive indicators of changes in soil properties caused by various management strategies. On the contrary, conventional physico-chemical parameters turned out to be insufficiently sensitive to detect relatively small changes in soil properties caused by farming practices over a short period. In our research, under the influence of nitrogen fertilization, the content of dehydrogenases, phosphatases and urease fit to a degree three curve, whereas the activity of proteases fit a degree four curve, with a very high coefficient of determination $\left(R^{2}=0.99\right)$.

Changes in soil enzymatic activity in the vegetation periods turned out to depend mainly on individual characteristics of the enzymes under study. An influence of study years on soil enzymatic activity was observed only in the case of phosphatases and protease. This regularity was also confirmed by other authors [44,54,55]. Ishaq et al. [56] suggest that for soil enrichment, it is necessary to make every effort to improve potential soil suitability for sweet potato cultivation, 
such as: mulching, irrigation, water retention, adding and retaining organic matter in soil, NPK and organic fertilization. So, enzymatic reactions can be used to study various aspects of soil science, such as: soil genesis, fertility, diagnosis, cultivation, salinity, erosion, and biological activity, which was confirmed by Bielińska and Mocek-Płóciniak [38] and Natywa et al. [37]. According to Futa et al. [57], Acosta-Martinez et al. [55] and Wang et al. [13], biological indicators of soil health offer bigger advantages over physico-chemical methods.Siwik-Ziomek and Szczepanek [58] showed that the actions of dehydrogenase, nitro reductase and urease are sensitive to mineral fertilization with NPK and its interaction with sulfur. Recent meta-analyses based mainly on data from unmanaged ecosystems suggest that increasing amounts of $\mathrm{N}$ influx suppresses soil microorganisms. Among the various biological indicators that have been proposed to monitor soil health, soil enzyme activity has great potential to provide a unique integrative biological assessment of soils and the possibility of assessing the health of the fauna and flora.Besides, soil enzyme activity provides an easy, relatively rapid procedure to monitor soil health.Nevertheless, soil enzyme activity also presents some limitations and must always be considered in conjunction with other biological and physico-chemical measurements if we are to diagnose soil health correctly.

The carbon to nitrogen ratio (C:N) affects the decomposition of organic matter. In mineral soil, it is most often 12:1. In plant residues, it varies, depending on the species; in legumes it is 20:1, and in cereals (55-100):1. As plants mature, their carbon content increases compared to nitrogen [38]. In the conducted studies, the C:N differentiation was observed, depending on the applied nitrogen fertilization. The correct $\mathrm{C}: \mathrm{N}$ ratio in the organic substrate, according to Bilińska and Płócienniczak [38] should be $24: 1$. This is due to the fact that $30 \%$ of the carbon is built into their bodies by microorganisms that break down organic matter. When this ratio is higher, the microorganisms begin to take available nitrogen from the soil, and then it is not enough for the plants. The process of incorporating nitrogen into the bodies of microorganisms is called nitrogen immobilization. On the other hand, the ratio lower than 20:1 causes the mineralization processes to prevail in the soil. There is nitrogen in the form of a mineral $\left(\mathrm{NH}_{4}{ }^{+}, \mathrm{NO}_{3}{ }^{-}\right)$, which is taken up by plants, but its excess is either washed away or evaporated. The conducted research proved a significant effect of nitrogen fertilization on increasing the content of total nitrogen and organic carbon in soil in objects fertilized with the dose of $100 \mathrm{~kg} \mathrm{~N} \mathrm{ha}^{-1}$. Further increase of nitrogen doses did not cause any significant changes in the content of these elements in the soil. Moreover, the increasing doses of nitrogen significantly reduced the value of the C:N ratio. This indicates an increase in the rate of mineralization and humification of organic matter in the soil and confirms the research hypothesis put forward in the introduction that the nitrogen fertilization used in the experiment significantly influences changes in nitrogen forms in the studied soil. The C:N ratio turned out to be significantly negatively related to the content of the enzymes Adh, AF, AU and $\mathrm{AP}$ as well as the content of total nitrogen, especially with its ammonium form $\left(\mathrm{N}-\mathrm{NH}_{4}\right)$.

Sweet potato nitrogen fertilization should be determined not only by the possibilities of achieving high tuber yield, but also by tuber and soil quality under sweet potato cultivation. The novelty of this research consisted in determining the relationship between the nitrogen dose and the biological activity of soil under sweet potato fertilization. So far, there has been no such research in Poland or in the world. This will enable reasonable, sustainable sweet potato nitrogen fertilization planning based on established phosphorus and potassium fertilization and provide the right biological value of soil and contribute to the development of sustainable agricultural systems that protect soil, water and air quality.

Identifying the absorption, transport, use and mobilization of nutrients according to sweet potato abilities should significantly increase nitrogen fertilization use efficiency [4]. Using new cultivars with higher NUE, in combination with the best fertilization management practices, will result in the development of sustainable agricultural systems that protect soil, water and air quality. 


\section{Conclusions}

In soils of most objects fertilized with nitrogen $(\mathrm{N})$, the activity of the analysed enzymes was significantly higher than in the control soil (without nitrogen fertilization), except for combinations fertilised with $150 \mathrm{~kg} \mathrm{ha}^{-1} \mathrm{~N}$ characterised by the highest accumulation of $\mathrm{N}^{-N_{3}}{ }_{3}^{-}$in soil. The intensity of biochemical processes in soil depended on the type of enzyme, which is connected to the individual enzyme sensitivity to environmental factors and the content of particular substrates for enzyme reactions in soil. The activity of dehydrogenases, phosphatases and urease changed as the nitrogen dose increased; a significant increase in their activity was recorded in objects with $50 \mathrm{~kg} \mathrm{ha}^{-1} \mathrm{~N}$. Another significant increase in the activity of dehydrogenases and phosphatases, as compared to the $50 \mathrm{~kg} \mathrm{ha}^{-1} \mathrm{~N}$ dose, was observed in variants fertilized with $200 \mathrm{~kg} \mathrm{ha}^{-1} \mathrm{~N}$. The increasing doses of nitrogen significantly reduced the $\mathrm{C}: \mathrm{N}$ ratio, which indicates an increase in the rate of mineralization and humification of organic matter. Analysis of simple correlation between enzymatic activity and physico-chemical characteristics of soil shows that dehydrogenase was highly positively correlated with phosphatase and urease and slightly less so with protease. The C:N ratio was significantly negatively related to the content of the enzymes Adh, AF, AU and AP as well as the content of total nitrogen, especially its ammonium form $\left(\mathrm{N}-\mathrm{NH}_{4}\right)$. However, soil acidity did not have a significant influence on either the enzymatic activity or physico-chemical characteristics of soil under the cultivation of sweet potato. The enzymatic activity of the enzymes under study turned out to be significantly positively related with the content of total nitrogen, ammoniacal nitrogen and carbon. The obtained results indicate the usefulness of research on enzymatic activity as an indicator of soil reaction to nitrogen fertilization. The results of this research are innovative and can influence the global production, yield and quality of sweet potato tubers, and at the same time keep arable soils in optimal biological balance.

Author Contributions: Conceptualization: B.S. and A.W.-K.; Data curation: B.S., E.J.B.; Formal analysis: B.S., A.W.-K. and E.J.B.; Funding acquisition: B.K.-M.; Methodology: B.S., A.W.-K, E.J.B. and B.K.-M.; Supervision: B.S., A.W.-K., B.K.-M., Validation: B.S., B.K.-M., P.P., P.B., D.S.; Writing-original draft: B.S., B.K.-M., A.W.-K., P.P., P.B.; Writing-review and editing: B.S., B.K.-M., P.P., P.B. and D.S. All authors have read and agreed to the published version of the manuscript.

Funding: This research received no external funding.

Conflicts of Interest: The authors declare no conflict of interest.

\section{Abbreviations}

$\begin{array}{ll}\text { Adh } & \text { dehydrogenase } \\ \text { AF } & \text { phosphatases } \\ \text { AP } & \text { protease } \\ \text { AU } & \text { urease } \\ \text { DEA } & \text { denitrifying enzyme activity } \\ \text { DP } & \text { denitrification potential } \\ \text { RESP } & \text { anaerobic respiration C-carbon } \\ \text { C:N } & \text { Carbon to Nitrogen ratio } \\ \text { Fm } & \text { maximum chlorophyll fluorescence } \\ \text { N } & \text { nitrogen } \\ \text { N-NH } & \text { Ammonium-Nitrogen } \\ \text { N-NO } & \text { Nitrate-NO } \\ \text { NPK } & \text { multicomponent mineral fertilizers containing nitrogen (N), phosphorus } \\ \text { NUE } & \text { (P) and potassium (K) in a form available to plants } \\ \text { PLFA } & \text { nutrient use efficiency } \\ \text { PS II (Y) } & \text { phospholipid fatty acid } \\ \text { qP } & \text { actual photochemical efficiency of photosystem PSII }\end{array}$




\section{References}

1. Hawkesford, M.; Kopriva, S.; De Kok, L.J. Efficiency in the use of nutrients in plants-Concepts and approaches. Jumper 2014. [CrossRef]

2. Brentrup, F.; Palliere, C. Efficiency of Nitrogen Consumption as an Agri-Environmental Indicator. 2017. Available online: http://www.oecd.org/tad/sustainable-agriculture/44810433.pdf (accessed on 23 June 2020).

3. Duncan, E.G.; O'Sullivan, C.A.; Roper, M.M.; Biggs, J.S.; Peoples, M.B. Wpływ jednoczesnego stosowania azotu $\mathrm{z}$ fosforem, potasem i siarką na pozorną wydajność stosowania nawozów azotowych, plon ziarna i zawartość białka w pszenicy. Field Crops Res. 2018, 226, 56-65. [CrossRef]

4. Rietra, R.P.J.J.; Heinen, M.; Dimkpa, C.O.; Bindraban, P.S. Effect of nutrient and antagonistic synergism on yields and fertilizer use efficiency. Commun. Soil. Sci. Plant Anal. 2017, 48, 1895-1920. [CrossRef]

5. Sawicka, B.; Michałek, W.; Pszczółkowski, P.; Danilčenko, H. Variation in productivity of sweet potato (Ipomoea batatas L. [Lam.]) under different conditions of nitrogen fertilization. Zemdirb. Agric. 2018, 105, 149-158. [CrossRef]

6. Sawicka, B. Efficiency of nutrient utilization for food security, sustainable development and resilience. In Encyclopedia of UN Sustainable Development Goals; Leal Filho, W., Azul, A., Brandli, L., Özuyar, P., Wall, T., Zero, H., Eds.; Springer: Cham, Switzerland, 2020; pp. 1-18. [CrossRef]

7. Solano, J.; Corrêa, C.; Gouveia, A.; Evangelista, R.; Cardoso, A.; Ming, L.C. The quality of sweet potatoes with different doses and separate application of nitrogen fertilizer. Acta Hortic. 2018, 1194, 79-84. [CrossRef]

8. Council Directive of 12 December 1991 Concerning the Protection of Waters against Pollution Caused by Nitrates from Agricultural Sources (91/676/EEC). 1991. Available online: https://eur-lex.europa.eu/legalcontent/EN/ALL/?uri=CELEX:31991L0676 (accessed on 14 December 2020).

9. Regulation of the Minister of the Environment of 23 December 2002 on Detailed Requirements to be Met by Action Programs Aimed at Limiting the Outflow of Nitrogen from Agricultural Sources, OJ 2003 No. 4 item 44; 2002. Available online: https://isap.sejm.gov.pl/isap.nsf/DocDetails.xsp?id=WDU20030040044 (accessed on 14 December 2020). (In Polish)

10. Regulation of the Minister of the Environment of 12 February 2020 on Detailed Requirements to be Met by Action Programs Aimed at Limiting the Outflow of Nitrogen from Agricultural Sources, OJ 2020 No. 4 item 243; 2020. Available online: https://isap.sejm.gov.pl/isap.nsf/DocDetails.xsp?id=WDU20200000243 (accessed on 14 December 2020). (In Polish)

11. Barabasz, W.; Albińska, D.; Jaśkowska, M.; Lipiec, J. Biological effects of mineral nitrogen fertilization on soil microorganisms. Pol. J. Environ. Stud. 2002, 11, 193-198.

12. Bielińska, E.J.; Mocek, A.; Paul-Lis, M. Impact of tillage system cultivation on enzymatic activity of typologically diverse soils. J. Res. Appl. Agric. Eng. 2008, 53, 10-13.

13. Wang, L.; Zhao, Y.; Al-Kaisi, M.; Yang, J.; Chen, Y.; Sui, P. Impact of seven different crop rotations on selected indicators of soil condition and wheat productivity. Agronomy 2020, 10, 235. [CrossRef]

14. Gostkowska, K.; Furczak, J.; Domżał, H.; Bielińska, E.J. Suitability of some biochemical and microbiological tests for the degradation degree of podzolic soil on the background of it differentiated usage. Pol. J. Soil Sci. 1998, 30, 69-78.

15. Sekaran, U.; McCoy, C.; Kumar, S.; Subramanian, S. Soil microbial community and enzymatic activity in the response to nitrogen management and landscape sites in switch grass (Panicum virgatum L.). Bioenergy 2019, 1-16. [CrossRef]

16. Bielińska, E.J.; Stankowski, S.; Maciorowski, R.; Meller, E.; Tomaszewicz, T.; Honzik, R.; Ustiak, S. Biological activity and certain physico-chemicalproperties of reclamation layers and brown coalblanket claystones of "strymickavysypka" object (Chomutov, Czech Republic). In Proceedings of the ISTRO-Conference Brno 2005, Troubsko, June 29-July 1 2005; Section II-Poster Presentation; International Soil Tillage Research Organization, Research Institute for Fodder Crops, Ltd.: Troubsko, Czech Republic, 2005; pp. 143-146, ISBN 80-86908-01-1.

17. Błońska, E.; Lasota, J.; Zwydak, M. The relationship between soil properties, enzyme activity and land use. For. Res. Pap. 2017, 78, 39-44. [CrossRef]

18. Krochmal-Marczak, B.; Cebulak, T.; Kapusta, I.; Oszmiański, J.; Kaszuba, J.; Żurek, N. The Content of Phenolic Acids and Flavonols in the Leaves of Nine Varieties of Sweet Potatoes (Ipomoea batatas L.) Depending on Their Development, Grown in Central Europe. Molecules 2020, 25, 3473. [CrossRef] [PubMed] 
19. Krochmal-Marczak, B.; Sawicka, B.; Tobiasz-Salach, R. Impact of cultivations technology on the yield of sweet potato (Ipomoea batatas L.). Emir. J. Food Agric. 2018, 30, 978-983.

20. WRB. World Reference Base for Soil Resources 2014 International Soil Classification System for Naming Soils and Creating Legends for Soil Maps; World Soil Resources Reports 106; Food and Agriculture Organization of The United Nations: Rome, Italy, 2014.

21. Bleinholder, H.; Weber, E.; Feller, C.; Hess, M.; Wicke, H.; Meier, U.; Boom, T.; Lancashire, P.D.; Buhr, L.; Hack, H.; et al. Growth Stages of Mono- and Dicotyledonous Plants; BBCH Monograph; Uwe, M., Ed.; Blackwell Wissenschafts-Verlag: Pairs, France, 2001; pp. 1-160.

22. Ngailo, S.; Shimelis, H.; Sibiya, J.; Mtunda, K. Growing sweet potatoes for resistance to sweet potato viral disease and increasing yields: Advances and challenges. Afr. J. Agric. Res. 2013, 8, 3202-3215. [CrossRef]

23. Mocek, A. Soil Science; State Scientific Publisher: Warszawa, Poland, 2015.

24. PN-R-04020, 1994+AZ1. In Chemical and Agricultural Analysis of Soil; Polish Committee for Standardization: Warszawa, Poland, 2004.

25. PN-R-04023. In Chemical and Agricultural Analysis of Soil. Determination of Available Phosphorus Content in Mineral Soils; Polish Committee for Standardization: Warsaw, Poland, 1996.

26. PN-R-0403. In Chemical and Agricultural Analysis of Soil, Sampling; Polish Committee for Standardization: Warsaw, Poland, 1997.

27. Fertilization Recommendations, Part I. Limits for the Evaluation of the Content in Macro-Soils Micronutrients; Institute of Soil Science and Plant Cultivation: Puławy, Poland, 1990; pp. 1-26.

28. Thalmann, A. ZurMethodik der Bestimmung der Dehydrogenase Aktivität in Boden MittelsTriphenyltetrazoliumchlorid (TTC). Landwirtschaft. Forsh. 1968, 21, 249-284.

29. Tabatabai, M.A.; Bremner, J.M. The use of p-nitrophenyl phosphate to determine soil phosphatase activity. Soil Boil. Biochem. 1969, 1, 301-307. [CrossRef]

30. Zantua, M.I. Urease Activity in Soils; Retrospective Theses and Dissertations an authorized administrator of Iowa State University Digital Repository 6234; Iowa State University: Ames, IA, USA, 1976.

31. Ladd, J.N.; Butler, J.H.A. Short-Term Assays of Soil Proteolytic Enzyme Activities Using Proteins and Dipeptide Derivatives as Substrates. Soil Biol. Biochem. 1972, 4, 19-30. [CrossRef]

32. Von Mersi, W.; Schinner, F. An improved and accurate method for determining the dehydrogenase activity of soil with iodonitrotetrazolium chloride. Biol. Fertil. Soils 1991, 11, 216-220. [CrossRef]

33. Wolińska, A. Dehydrogenase activity of soil enzymes and oxygen availability in the reoxidation process of selected mineral Polish soils. Dissertations and Monographs. Acta Agroph. 2010, 180, 1234-4125.

34. SAS. Enterprise 4.2 Program SAS/STAT ${ }^{\circledR}$ 9.2. Users Guide; SAS: Raleigh, NC, USA, 2008.

35. Trętowski, J.; Wójcik, A.R. Methodology of Agricultural Experiments; Agricultural and Pedagogical University in Siedlce: Siedlce, Poland, 1991; pp. 331-334.

36. Warzyński, H.; Sosnowska, A.; Harasimiuk, A. Effect of variable content of organic matter and carbonates on results of determination of granulometric composition by means of Casagrande's areometric method in modification by Prószyński. Soil Sci. Ann. 2018, 69, 39-48. [CrossRef]

37. Natywa, M.; Sawicka, A.; Wolna-Murawka, A. Microbial and enzymatic activity in the soil under maize crop in relation to differentiated nitrogen fertilisation. Water Environ. Rural Areas 2010, 10, 111-120.

38. Bielińska, E.J.; Mocek-Płóciniak, A. Impact of the tillage system on the soil enzymatic activity. Arch. Environ. Protect. 2012, 38, 75-82. [CrossRef]

39. Koper, J.; Piotrowska, A.; Siwik, A. The index of soil fertility in a long-term experiment with crop-rotation and monoculture. Probl.NotebooksProgr. Agric. Sci. 1999, 465, 461-470.

40. Majchrzak, L.; Sawinska, Z.; Natywa, M.; Skrzypczak, G.; Głowicka-Wołoszyn, R. Impact of Different Tillage Systems on Soil Dehydrogenase Activity and Spring Wheat Infection. J. Agric. Sci. Technol. 2016, $18,1871-1881$.

41. Vetanovetz, R.; Peterson, J. Effect of carbon source and nitrogen on urease activity in a sphagnum peat medium. Commun. Soil Sci. Plant Anal. 1992, 23, 379-388. [CrossRef]

42. Burns, R.G.; DeForest, J.L.; Marxsen, J.; Sinsabaugh, R.L.; Stromberger, M.E.; Wallenstein, M.D.; Weintraub, M.N.; Zoppini, A.M. Soil enzymes in a changing environment: Current knowledge and future directions. Soil Biol. Biochem. 2013, 58, 216-234. [CrossRef]

43. Trevors, J.T. Effect of substrate concentration, inorganic nitrogen, $\mathrm{O}_{2}$ concentration, temperature and $\mathrm{pH}$ on dehydrogenises activity in soil. Plant Soil 1984, 77, 285-293. [CrossRef] 
44. Brzezińska, M.; Włodarczyk, T. Enzymes of intracellular redox transformations (oxidoreductases). Acta Agroph. 2005, 3, 11-26.

45. Yang, L.; Li, T.; Lemcoff, J.H.; Cohen, S. Fertilization regulates soil enzymatic activity and fertility dynamics in a cucumber field. Sci. Hortic. 2008, 116, 21-26. [CrossRef]

46. Kucharski, J.; Ciećko, Z.; Niewolak, T.; Niklewska-Larska, T. Activity of microorganisms in soils classified as various agricultural utility complexes fertilized with mineral nitrogen. Acta Acad. Agric. Tech. Olst. Agric. 1996, 62, 25-35.

47. Smyk, B.; Różycki, E.; Barabasz, W. Impact apply mineral nitrogen fertilizers (N and NPK) on occurrence of nitroisoamines and mycotoxins in mountain soils grassy ecosystems. Probl. Notebooks Progr. Agric. Sci. 1989, 380, 151.

48. Natywa, M.; Selwet, M.; Maciejewski, T. Effect of some agrotechnical factors on the number and activity soil microorganisms. Frag. Agron. 2014, 31, 56-63.

49. Tarafdar, J.C.; Classen, N. Organic phosphorus compounds as a phosphorus source for higher plants through the activity of phosphates produced by plant roots and microorganisms. Biol. Fert. Soils 1988, 5, 308-312. [CrossRef]

50. Šimek, M.; Hopkins, D.W. Regulation of potential denitrification by soil pH in long-term fertilized arable soils. Biol. Fert. Soils 1999, 30, 41-47. [CrossRef]

51. Nazarkiewicz, M.; Kaniuczak, J. Effect of liming and mineral fertilization on the enzymatic activity of grey-brown podzolic soils formed from loess. Pol. J. Soil Sci. 2008, 12, 2001-2007.

52. Koper, J.; Lemanowicz, J.; Igras, J. The effect of fertilization on the phosphatase activity and the content of some phosphorus forms. Ann. Univ. Mariae Curie Skłodowska 2004, 49, 679-686.

53. Mijangos, I.; Perez, R.; Albizu, I.; Garbisu, C. Effects of fertilization and tillage on soil biological parameters. Enzyme Microb. Technol. 2006, 40, 100-106. [CrossRef]

54. Mona, E.E.; Ibrahim, S.A.; Manal, M. Combined effect of NPK levels and foliar nutritional compounds on growth and yield parameters of potato plants (Solanum tuberosum L.). Afr. J. Microbiol. Res. 2012, 6, 5100-5109.

55. Acosta-Martinez, V.; Cano, A.; Johnson, J. Simultaneous determination of the activity of many soil enzymes for biogeochemical indicators of soil health. Appl. Soil Ecol. 2018, 126, 121-128. [CrossRef]

56. Ishaq, U.M.; Umara, B.; Armanto, H.M.; Adzemi, M.A. BRIS Soil Suitability Assessment 2 on Sweet Potato in Merang-Terengganu Region of Malaysia. J. Biol. Agric. Healthcar. 2014, 4, 11-19.

57. Futa, B.; Bielińska, E.J.; Mocek-Płóciniak, A. The use of enzymatic tests to assess the quality of arable soils along main thoroughfares inulin. J. Res. Appl. Agric. Eng. 2016, 61, 94-97.

58. Siwik-Ziomek, A.; Szczepanek, M. Soil Extracellular Enzyme Activities and Uptake of N by Oilseed Rape Depending on Fertilization and Seaweed Biostimulant Application. Agronomy 2019, 9, 480. [CrossRef]

Publisher's Note: MDPI stays neutral with regard to jurisdictional claims in published maps and institutional affiliations.

(C) 2020 by the authors. Licensee MDPI, Basel, Switzerland. This article is an open access article distributed under the terms and conditions of the Creative Commons Attribution (CC BY) license (http://creativecommons.org/licenses/by/4.0/). 